\title{
420 焼結米糠が入った射出成形プラスチック歯車の強度と騒音
}

\section{Strength and Noise of the Injection Molded Plastic Gear Included Rice Bran Ceramics}

\author{
正 高橋秀雄（木更津高専）正 飯塚 博（山形大）
}

Hideo TAKAHASHI, Kisarazu National College of Technology,

Hiroshi IIZUKA, Yamagata University

$$
\text { 2-11-1, Kiyomidai-Higashi, Kisarazu 292-0041 }
$$

Many factors have effect on load carrying characteristics of the injection molded plastic spur gear pair. One of them is the plastic materials. In especial, the temperature in plastic materials is the most important item, because high temperature in plastic materials causes decrease in the modulus of longitudinal elasticity. Therefore, the effect of each condition, such as the transmitting torque and the kind of plastic materials, on the bulk temperature of gear was investigated. In addition, the measurements of strength and noise of gear were done. The test gears were made from standard POM and POM included new porous carbon materials. As a result, the effects of plastic materials were found.

Key Words: Plastic Gear, Spur Gear, Bulk Temperature, Composite Materials, Strength, Noise.

\section{1. 緒 言}

プラスチック歯車は, プラスチック自体の自己潤滑性等の特 長を生かしたところで多く利用されている. 例えば, OA機器 などのように比較的に低負荷の動力伝達部への利用が飛躍的に 増大している(1), (2). そのために, プラスチック歯車の強度評価 に関する多くの報告がなされている( ${ }^{(3)}$.

また, A V機器, 精密機械などの分野においてはプラスチッ ク歯車の低騒音化が求められている. そこで, 材料面では摺動 性や低弾性率材料の開発が行われ, 歯車騒音低減法では, 歯車 精度, 歯面の粗さ，歯車形状などの騒音に及ぼす影響の検討が なされてきた(2).

一方，近年，機械的性質およひ環境面で優れた材料として， 米糠セラミックスが注目されている( ${ }^{(4)}$. 米糠を原料とした米糠セ ラミックスは，精米時に発生した米糠を焼成して作られたもの で，摩擦抵抗が非常に低い，高硬度である，軽いと言った特長 により直線運動軸受のスライダ部等に使用されている.

本研究では，合成高分子材料のプラスチックと天然素 材の米糠セラミックスによる高性能・高機能材料の歯車 材料への適用性を検討する. 具体的には, 米糠セラミッ クスを添加したポリアセタールと無添加のポリアセター ルを用いて射出成形された歯車に対して, 負荷トルクを 変更し, かみ合い部本体温度，および騒音を測定した。 その結果，いくつかの新たな傾向を見出したので報告する.

\section{2. 実験条件}

\section{1 試験雬車}

本研究で使用した試験歯車の基本諸元を表 1 に示寸，歯車の 精度は，旧 JIS4 級で一般的に普及している標準的な射出成形プ ラスチック平歯車である.

菌車材料は，標淮的なポリアセタールを基本材料とし，その ポリアセタールだけで作られた歯車（以下，無添加と記す.）， ポリアセタールに粒度 $30 \mu \mathrm{m}$ の米糠セラミックスを $10 \mathrm{wt} \%$ 添加

Table 1 Dimensions of test gear

\begin{tabular}{|lc|c|}
\hline Module & $\mathrm{m}[\mathrm{mm}]$ & 0.8 \\
\hline Cutter press. Angle & $\alpha_{\mathrm{c}}[\mathrm{deg}]$ & 20 \\
\hline Number of teeth & $\mathrm{z}$ & 56 \\
\hline Addendum modification coeff. $\mathrm{x}$ & 0 \\
\hline \multicolumn{2}{|l|}{ Tooth width $[\mathrm{mm}]$} & 5 \\
\hline
\end{tabular}

した柬車 (以下, $30 \mu$ と記す.) および粒度 $60 \mu \mathrm{m}$ の米棣セラミ ックスを $10 \mathrm{wt} \%$ 添加した歯車 (以下, $60 \mu$ と記す.) の三種類を 設定した。

\section{2 実験方法}

本研究における実験は, 動力吸収式歯車試験機を用いて行っ た（図 1). 歯車対は，モータで駆動され，負荷はブレーキに より加えられる。

実験結果の一例を図 2 に示す．実験条件は，回転数を $500 \mathrm{rpm}$ で一定とし，負荷トルクは図中に示寸ように $0.5 \mathrm{Nm}$ から $1.5 \mathrm{Nm}$ までは $0.5 \mathrm{Nm}$ 刻み, $1.5 \mathrm{Nm}$ からは $0.25 \mathrm{Nm}$ 刻みで損傷に至るまで 段階的に増加させた場合である. 図から明らかなように, 負荷 トルク毎にかみ合い部本体温度が異なる.

そこで, 各負荷トルクにおいて，かみ合い部本体温度を測定 し，平衡状態となった温度（図中○印）をその負荷トルクにお けるかみ合い部本体温度の代表值とした. さらに, 平衡温度状 態となった時の騷音を測定し, FFT アナライザによって周波数分 析を行なった．ただし，歯車対のかみ合い時における歯面間の すき間であるバックラッシは, $0.1 \mathrm{~mm}$ とした.

\section{3. 実験結果}

\section{1 本体温度上昇}

図 3 に歯車材料の成分の違いによる歯車強度への影響を示す. 縦軸の本体温度は各負荷トルクで運転し、平衡温度に達した際 のかみ合い部本体温度である. 一般にプラスチックの物性值が 温度に依存することから，ほぼ同一の雾囲気温度の下で実験を 実施した. 米糠を添加した歯車は, 無添加の歯車に比べ, やや高

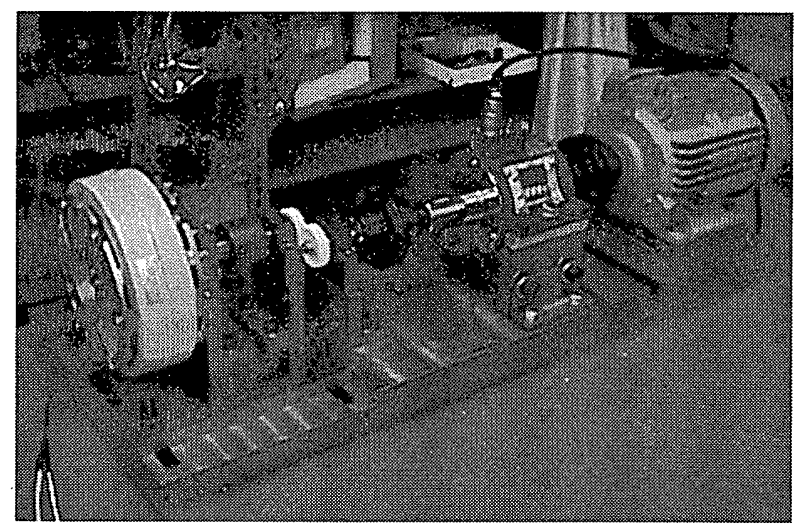

Fig.1 Test rig.

[No. 04-17] 日本機械学会機素潤滑設計部門 MPT2004 シンポジウムく伝動装置＞講演論文集 [2004.11.26〜27] 


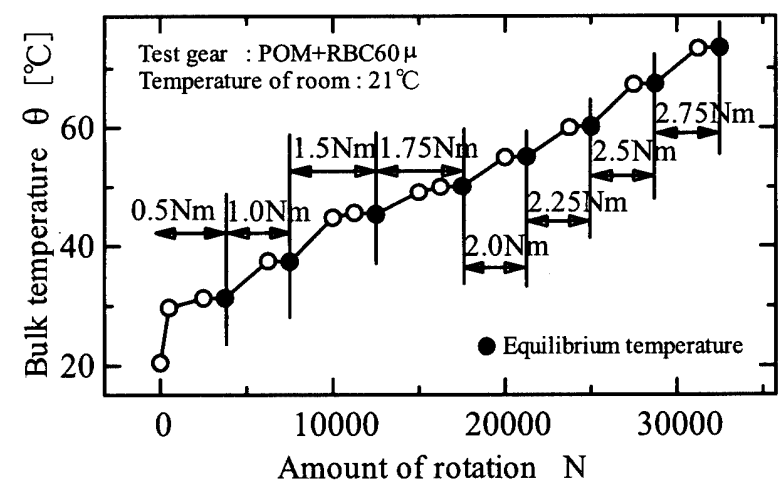

Fig.2 Relationship between bulk temperature and torque.

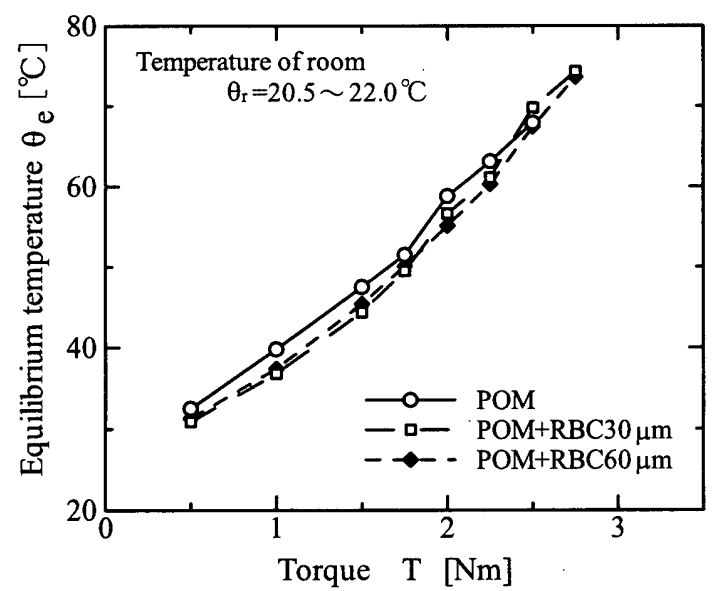

Fig.3 Change in torque and ensuing equilibrium temperature.

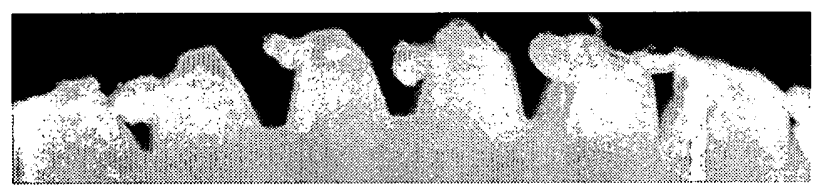

(a) Standard POM (Temp. of room $21^{\circ} \mathrm{C}$, Torque $2.5 \mathrm{Nm}$ )

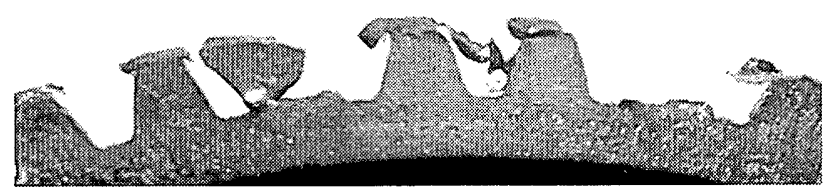

(b) $\mathrm{POM}+\mathrm{RBC} 30 \mu \mathrm{m}$ (Temp. of room $22^{\circ} \mathrm{C}$, Torque $2.75 \mathrm{Nm}$ )

Fig.4 Damage form.

い負荷に耐えるという結果を得た。 また，温度上昇に注目すると。 無添加の歯車に比べ米糠を添加した歯車は, かみ合い部本体温 度上昇が低い傾向を示している。

\section{2 損傷形態}

図 4 に歯車材料の成分の違いによる損傷形態を示す．図中の (a) は無添加ポリアセタール, (b) は米棣粒度 $30 \mu \mathrm{m}$ 添加ポリア セタールであり，雾囲気温度はほぼ同条件の下での結果である. 無添加ポリアセタール歯車は, 負荷トルク $2.5 \mathrm{Nm}$ で損傷し, そ の損傷形態は歯面溶融が主であった。これに対し米棣粒度 $30 \mu$ を添加したポリアセタールは負荷トルク $2.75 \mathrm{Nm}$ で損傷し，損傷 形態は溶融及び折損であった。この傾向は，実験を行った全て の歯車で同様であった.

\section{3 歯車騒音}

図 5 に比較的低負荷での，騒音特性におよぼす歯車材料成分

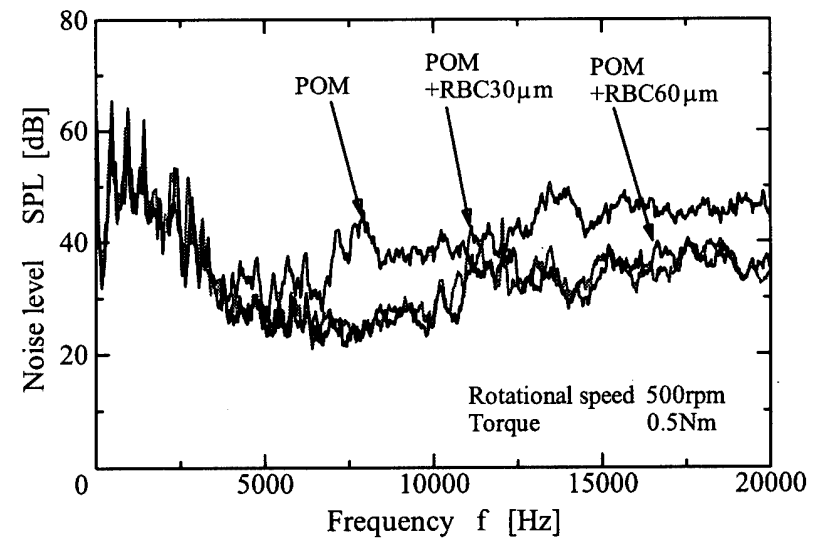

Fig.5 Noise level of spur gears.

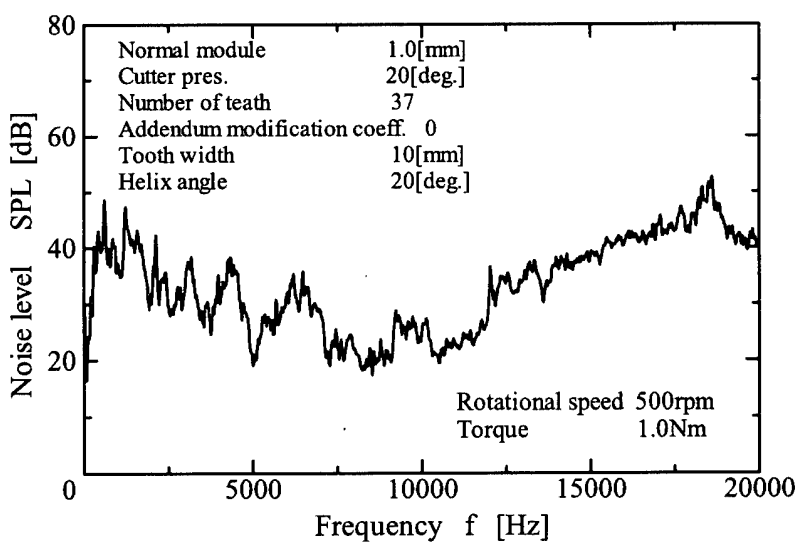

Fig.6 Noise level of helical gear.

の影響について示す，歯車のかみあい周波数が現れる低周波域 での騒音レベルにおいては, 米棣セラミックス添加の有無によ る大きな差は認められない. しかし, $4 \mathrm{kH} \mathrm{z}$ 以降の周波数帯域 では無添加歯車に比べ, 米糠セラミックスを添加した歯車の騒 音レベルが低くなっている. すなわち，歯面摺動特性が向上し ていることが分る.この傾向は，低負荷において顕著に観察さ れた，また，米糠セラミックス粒度の影響は，特に認められな かった，一般に平歯車においては，騒音レベルのピークが低周 波域に存在する為, 高周波域での騒音レベル差を人間の聴覚で は判別できない，しかし，はすば歯車の様に騒音レベルのピー クが高周波側にある場合では，米糠セラミックスを添加するこ とにより摺動音が改善され，聴覚的に違いが出る可能性がある (図6).

\section{4. 結 言}

ポリアセタールに米糠セラミックスを添加した材料を用いて， 射出成形された平歯車の本体温度と騒音を測定した結果を要約 すると以下のとおりである。

（1）無添加歯車に比べ, 高負荷に耐える可能性がある.

（2）損傷形態が無添加の場合と異なる.

（3）低負荷の高周波領域において, 騒音レベルの低减が認め られる。

(参考文献省略) 